\title{
THE BIBLICAL WORLD
}

CONTINUING

The Old and New Testament Student

Volume vi. DECEMBER, i 895 Number 6

\section{FORESHADOWINGS OF THE CHRIST IN THE OLD TESTAMENT.}

By William R. HaRPer,

The University of Chicago.

THE Greeks stood alone among the nations of the earth in their appreciation of the beautiful; the Romans in their interest and skill in organization. The Hebrew nation stood alone in its overwhelming sense of the heinousness of sin. This thought controlled all their thoughts. Finding themselves in the midst of sorrow, wretchedness, and death, all of which are the result of sin, they began in the earliest periods to look for deliverance. The idea of the character of sin was implanted in the Hebrew heart for a purpose. This purpose, as it developed, revealed the divine plan for man's relief from the consequences of sin. In a study of these thoughts and utterances which look forward to the Christ, one must consider the subject from the point of view not only of the divine plan, but also of the human expectation. Israelitish history, wrought out according to a divine purpose to furnish a basis for the development of the plan, falls into several distinct divisions, each division marked by certain great characteristics.

I. Recalling the history of Abraham, the patriarchs who follow him, the residence in Egypt, the exodus, the giving of the law, the wandering in the wilderness, the death of Moses, and 


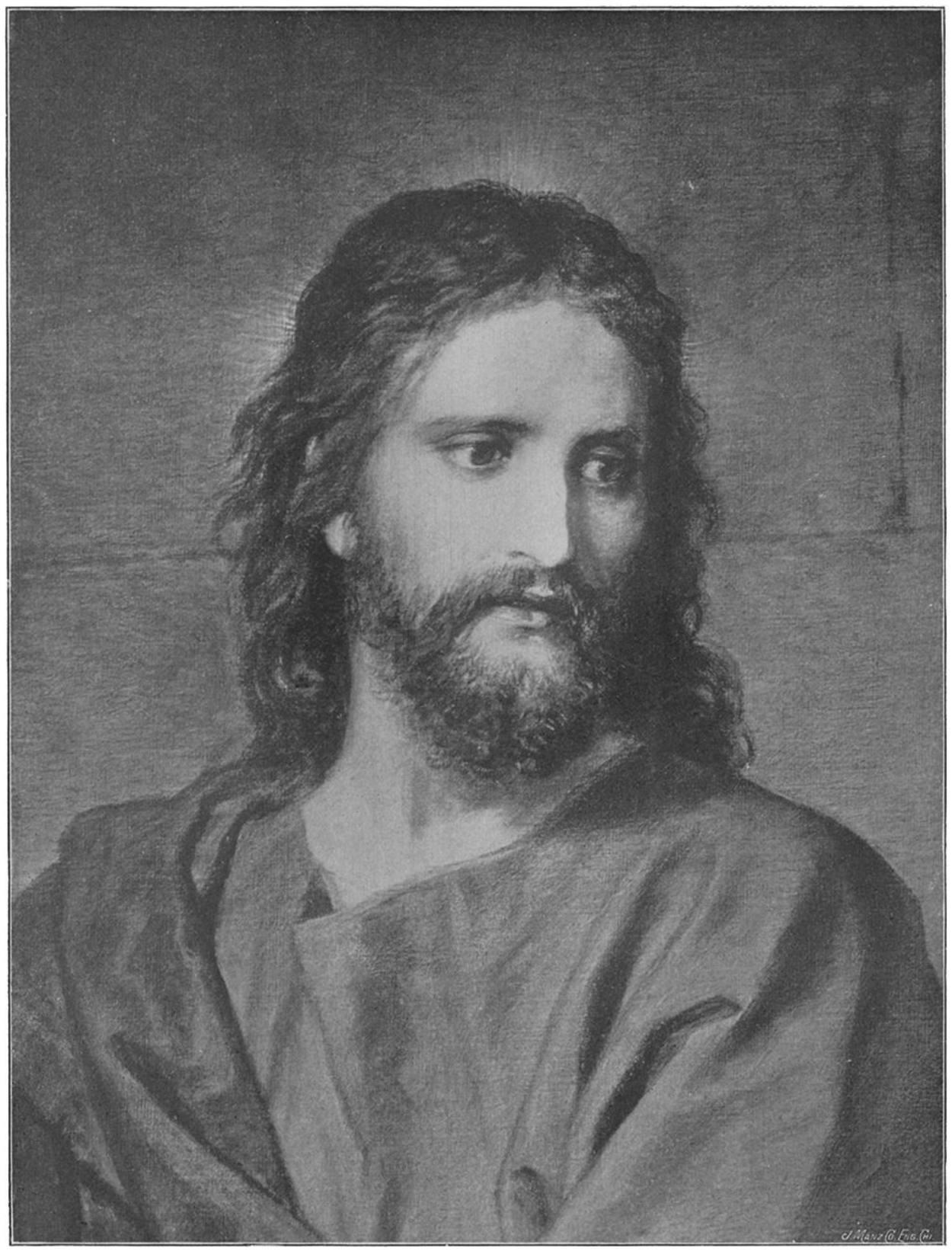

This content downloaded from 129.100.058.076 on November 27, 2016 07:20:21 AM All use subject to University of Chicago Press Terms and Conditions (http://www.journals.uchicago.edu/t-and-c). 
the conquest, we may ask: How definite at the time of Moses' death had the expectation of this deliverance become? and how definite at this time were the promises which had been made from heaven? The destiny of man as a ruler of the world is fully appreciated, as well as the endowment given him by God through which his destiny may be attained, namely, creation in the image of God. ${ }^{x}$ The nature of the conflict between man and the powers of evil has become apparent. The struggle will continue for ages, but in the end the woman's seed shall be victorious over the seed of the serpent, though receiving injury in the conflict. ${ }^{2}$ The necessity of the close indwelling of God in the midst of men is appreciated, and men believe that God will in a special manner take up his dwelling in the tents of Shem. ${ }^{3}$ It is evident that in the successful prosecution of the plan, one nation from all the nations of the earth must be selected, guided, and educated, and it is believed by the Hebrew nation that their ancestor Abraham was thus selected, ${ }^{4}$ and that to him a promise was made of a country and a great posterity through which the world shall be blessed. A tradition also exists to the effect that this blessing was transmitted from Abraham to Isaac, from Isaac to Jacob, 5 and that from the sons of Jacob, Judah was selected to be the leader; his supremacy to continue until the conquest of the promised land. ${ }^{6}$ As time passes on and Israel, having left Egypt, becomes a nation, the feeling gains ground that Israel, in order to accomplish her work, shall be a kingdom of priests. ${ }^{7}$ Balaam, hired to preach against Israel, sees the nation, with the insignia of royalty, destroying her enemies round about. ${ }^{8}$ If the Israelitish nation as a nation is to be a mediator to nations, it soon becomes apparent that for this work a special order of men should be set aside,- - the priestly order. ${ }^{9}$ In order that the nation may be guided aright, and not be compelled to resort to necromancers and wizards, there shall be raised up from time to time prophets who shall speak to them the law of God. ${ }^{\circ}$ More than

\footnotetext{
I Gen. I : 26-30.

5 Gen. $27: 27-29$.

9 Num. 25: I 2, I3.

${ }^{2}$ Gen. $3:$ I 4, 15.

${ }^{6}$ Gen. 49 : 8-I 2.

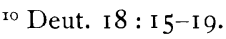

3 Gen. 9:25-27.

7 Ex. I9 : 3-6.

4 Gen. I I : 26-I $2: 3$.

8 Num. 24 : I 7-I9.
} 
this, Israel, in order to perform properly her mission among the nations of the earth, must, like other nations, have a king, a royal king. The thought of the period, therefore, seems to have connected itself with the line through which the deliverance is to be wrought; the land in which the great drama of deliverance is to be played; the means of deliverance, namely, the chosen people, and the special agencies by which the chosen people shall effect the divine purpose, a priestly order, a prophetic order, and a royal order.

2. In the period of Samuel, Saul, David, and Solomon, the idea of royalty is uppermost in the minds of the people. A monarchy is established. The king who shall sit upon the throne represents Jehovah; he is, however, subordinate, not only to Jehovah, but to Jehovah's messenger, the prophet. In this period the temple is erected and Jehovah is understood to take up his dwelling in the temple, a great advance upon the dwelling in the tents of Shem. ${ }^{2}$ The promise is made that David's seed shall be established upon David's throne and that he shall be, indeed, the son of God as beforetime Israel had been called God's son. ${ }^{3}$ The king with Jehovah at his side shall rule over Zion. His army, made up of countless youth, shall march as volunteers under his banner. Guided by Jehovah he will win the victory upon the blood-drenched, corpse-covered battlefield, and with unrelenting vigor will pursue the conquered and defeated enemy. ${ }^{4} \mathrm{His}$ reign will be characterized by peace and mercy; it will be universal and everlasting. 5 The whole thought of the period turns upon the idea of the king; and what could be more natural, in this early age, and at a time in which the thought which filled the minds of all the people was that of an earthly kingdom. The king described in this ideal manner did not come in the period in which he was expected. When at last he did come, he was not the king that had been described. He was, however, something greater than even Israel's prophetic vision had foretold.

3. In the southern kingdom after the division there is little or no prophetic impulse. Here the monarchy and the priesthood

I Deut. I 7 : I4-20.

32 Samuel 7 : I I-I6; Ps. I $8: 43-50$.

2 Ps. 24.

4 Ps. I Io.

5 Ps, 72. 
were supreme and the visions of the prophets were rare. In the northern kingdom, however, after a century or so, there begins a prophetic activity which is most marked. Elijah, with a sternness and severity almost indescribable, bewails the apostacy of his times. ${ }^{\mathrm{T}}$ Elisha, beneficent and courteous, endeavors by diplomacy to advance the interests of the kingdom. ${ }^{2}$ The schools of the prophets, founded back in the times of Samuel, are greatly strengthened, and their work certainly assists in promulgating a truer conception of the Jehovah religion. ${ }^{3}$ At this time, likewise, Jonah makes his trip to Nineveh and by his preaching of the word brings Nineveh to repentance. ${ }^{4}$ But in all this work the sins of the times and the profligacy of the period are dwelt upon, and, seemingly, the prophets have little strength left with which to picture the ideals of the future. Amos preaches sermon after sermon upon the text "Punishment for $\sin ^{.}{ }_{5}$ He publishes vision after vision, all of which foretell the coming of judgment and destruction upon the people. ${ }^{6}$ His prophetic eye, however, sees beyond the coming of the Assyrian army and the devastation which it shall work, and in the far distant future he beholds the tent of Darid which has been broken down, again restored; 7 the holy land full of harvests and consequent prosperity, Israel gathered again from the four corners of the earth and restored to home. Hosea sees as clearly as did Amos the coming destruction $;^{8}$ he sees also what has not been seen so clearly before, the intense love of Jehovah for his people and his readiness to forgive. ${ }^{9}$ Hosea feels that punishment must come on account of the iniquity of the times; but after this punishment has been executed, he beholds, as did Amos, the restoration of Israel to her land. ${ }^{\text {ro }}$ In all this period there has been slight thought of the deliverance from sin, because the minds of the people are filled with the thought and the need of the deliverance from an immediate calamity. This idea is so close as to drive away the magnificent conceptions of earlier days. On the other hand, it must

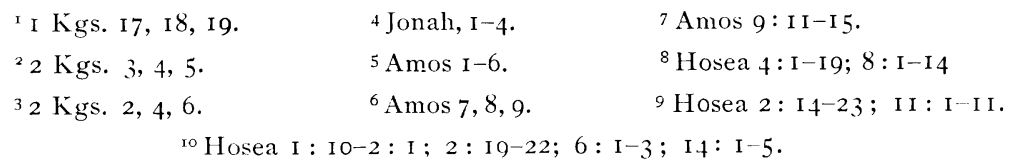


be noted that restoration of Israel from captivity is in itself a pledge of the fulfilment of Jehovah's promise, and to this extent the foreshadowing of the great future which lies beyond.

4. The Assyrian times have at last arrived. Isaiah predicts the desolation of Israel, and indicates the sins of the people, which are the occasion of the impending destruction. Yet, beyond this destruction, both he and Micah see the exaltation of the mountain of Jehovah's house, the universal acknowledgment of Jehovah as king, and the introduction of an era of universal peace. ${ }^{x}$ When Judah is invaded by Pekah and Rezin, Isaiah announces the coming of a child born of a virgin, whose name shall be called Immanuel; ${ }^{2}$ and before this child shall be able to distinguish good and evil, the Assyrian invasion will have taken place. Somewhat later, when Tiglathpileser carries away captive the tribes of Zebulon and Naphtali, and the people of Jerusalem are panic-stricken because of this, the beginning of the fulfilment of the prophecies of destruction, Isaiah preaches ${ }^{3}$ the coming of light in the midst of darkness; of joy and freedom, instead of grief and captivity; of the abolition of war; and all this because of the child that is yet to be born, whose name is given as the Wonder of a Counselor, God of a Hero, Father of Booty, Prince of Peace. Samaria falls ( 722 B. C.), in accordance with the prediction of the prophets; but the judgment is not yet finished. Terrible judgments are yet to come, but they will be followed by times of rejoicing, in which those faithful to Jehovah shall no more be ashamed. ${ }^{4}$

Sennacharib now (70I B.C.) appears in Palestine. Though the army is near at hand, the prophet tells of a righteous judge of the line of David who shall rule the nation in peace, and in the knowledge of Jehovah. ${ }^{5}$ Although Hezekiah surrenders to the Assyrian army, ${ }^{6}$ Isaiah repeats his prediction that the enemy will be scattered, and describes the time when the righteous man shall see the king in all his beauty, and shall dwell with him in Zion. ${ }^{7}$ The Assyrian army is smitten with death and Jerusalem

I Isa. $2: 2-4$, Mic. $4: 1-5$; Isa. $4: 2-6$.

${ }^{2}$ Isa. $7: 1-25$.

3 Isa. $8:$ I6-9: 7 .
${ }^{4}$ Isa. 28 .

5 Isa. 10:5-12:6.
${ }^{6} 2$ Kgs. I $8:$ I 4 .

7 Isa. 33 . 
delivered. ${ }^{x}$ On the days that follow songs of joy are sung to heaven, celebrating the city of God as a place of safety and peace for the people; a place of beauty and strength; and a wonder to nations. ${ }^{2}$ A cornerstone shall be established in $\mathrm{Zion} ;{ }^{3}$ and out of Bethlehem from the line of David shall come a righteous ruler, who shall lead Judah against the Assyrians. ${ }^{4}$

As before, the thought of the nation seems to have exhausted itself in dwelling upon the perplexities of the day, and yet, in contrast with the dark pictures which the prophet presents, he portrays the brightness of the coming future. Isaiah expects to see the coming of deliverance in connection with the Assyrian invasion. The Assyrian army came again and again, and the expectations of the prophet were disappointed. He is continually looking for the birth of a child. At first, in the days of Ahaz, when he predicts the birth of Immanuel, and later the child, whose name shall be called Wonder of a Counselor, and, twenty-five years later, in the days of Hezekiah, when Sennacherib has led his army into Judah. Isaiah's hopes were not destined to be realized in his own days; but centuries later, when the fulness of time had come, the child was born, as different from the picture of Isaiah's child as was the actual character of the king in comparison with the picture of royalty outlined in David's times. The thought, however, was none the less real; and the hope of the coming deliverance lifted up many a follower of Jehovah in his despondency.

5. The next age is that of Jeremiah and the fall of Jerusalem. Zephaniah sees a coming destruction and, beyond it, restoration, prosperity, and honor. ${ }^{5}$ Jeremiah is so occupied with the evils of his times and his own sufferings as to allow little time for the contemplation of the future, and indeed it was difficult even for a prophet of Jehovah to see much that was encouraging in the future. For how could a prophet reconcile himself to the destruction of Jerusalem? And yet Jeremiah is able to do this very thing. In imprisonment he predicts a restoration after the captivity and describes the righteous branch which shall rule in

Isa. $37: 36,37$.
2 Pss. $46,48$.
${ }^{3}$ Isa. $28:$ I4-18; Ps. I I $8: 22,23$.

4 Mic. $5: \mathrm{I}-9$. 
righteousness. ${ }^{x}$ Under arrest he promises to those about him relief and restoration and a future time of protection, prosperity, and honor. ${ }^{2}$ He preaches of the establishment of a new covenant and the coming of a time when all men shall know Jehovah. ${ }^{3}$ As truly as Jerusalem shall be destroyed, so surely shall the people of Israel be restored, ${ }^{4}$ and again Jeremiah furnishes promises of Messianic glory. 5 When Jerusalem is laid waste, there devolves upon the prophet the task of reconciling God's promise of eternal prosperity with the present condition of things. This naturally leads them to the consideration of something higher than the city itself; a dwelling with God more ideal than an actual dwelling in the temple. ${ }^{6}$ The place of the fall of Jerusalem in the history of prophetic thought is most significant.

6. What form does the expectation of deliverance assume when Israel, far from home and native land, finds herself in the Babylonian exile? Ezekiel, on the banks of the Chebar, tells again and again of restoration of the faithful Israel $;^{7}$ the resurrection of dry bones $;{ }^{8}$ the reunion of the northern and southern Israel. 9 This indeed is the only note of encouragement which a prophet could preach, for how can there be fulfilment of any of the promises of the past unless first Israel is restored to her native land. Can we put ourselves in the position of the faithful Jews in captivity? While living in Jerusalem before its destruction, they were loyal to the worship of Jehovah, having never been guilty of idolatry. Yet, notwithstanding this faithfulness on their part they are now in captivity. Their sufferings are intense since they are driven away from home and deprived of the opportunity to worship their God. Their brethren, on every side, reproach them because of the inability of the God whom they serve to relieve their sufferings. Their anguish is increased because they believe this suffering to have been sent upon them by God. Why has he deserted them? Why has he driven them away and placed them in the power of their enemies? Have they sinned against him? No. Why was

'Jer. $23: 1-8$.

2 Jer. $30: 3^{-22}$.

3 Jer. $3 \mathbf{I}$.
4 Jer. 32.

5 Jer. 33.

${ }^{6}$ Pss. 89, I 32.
7 Ezek. I I : 14-20; 17 : 22-24.

${ }^{8}$ Ezek. 37 : I-14.

9 Ezek. 37 : 1 5-28. 
their property distributed to their enemies? Had they been faithless to Jehovah? No. What then is the occasion of their sufferings? The sins of the nation as a whole. It is because Israel abandoned Jehovah that Israel is now in captivity. They are then suffering because of the sins of others and not because of their own sins. The Israelites who were faithless to Jehovah suffer little on account of the captivity. They did not care for the temple worship or Jehovah; they are well situated in Babylon. Their souls are not tried because Jehovah has abandoned them, since they had first abandoned Jehovah. The real sufferers are those who were faithful. But what is to be the outcome? It is necessary that these faithful ones continue to suffer with those who have sinned and because of their sins, in order that the future may bring a fulfilment of the great promises of Jehovah. If in their distress they turn away from Jehovah, there will be no remnant to whom the promise may be fulfilled. They suffer, therefore, in order to secure future blessings to those who shall follow them. This suffering remnant is the servant of Jehovah; the agent through which a new religion is to be introduced into the world. The nation Israel includes the servant and is sometimes represented as the servant. The prophet in the midst of the captivity predicts that this servant shall be exalted very high. ${ }^{x} \quad$ He realizes, however, that preceding this exalation there is and will be a humilation. The servant sent to carry to the world the message of its deliverance from $\sin$ is not recognized, since no one believes the report which has been given of him and no one sees in his coming the indication of the power of Jehovah. Why is he not recognized? Because he has grown up as a sucker, that is, something superfluous; as a root out of dry ground, that is, without juice or sap; with no comeliness or beauty; and consequently he was despised and deserted. This was the estimation in which he was held by those about him who did not understand his mission. The real fact in the case was that he suffered, but only for the sins of others, and indeed, for the sins of those very persons who, in their blindness, regarded him as stricken with leprosy. It was

\footnotetext{
I Isa. $52:$ I I-53:I 2 .
} 
they who had gone astray while on him the iniquity was laid. In all this suffering, though treated rigorously, there was no complaint. Though treated unjustly, his contemporaries did not see that he was suffering for his people. His end was an inglorious one. But in return for the sufferings of the servant, God had proposed to prolong his days and accomplish through him a divine work. He, the servant, will render many righteous ; he will receive great reward; he will be treated as a conqueror. Thus the great thought of the exile should be interpreted; but the return and the restoration of spiritual Israel to Jerusalem as a reward of faithfulness, did not exhaust the thought; it is an ideal description, which includes the suffering servant who, centuries later, was to do for all men and all time what the faithful remnant of Israel did for the times of captivity.

The assurance is given that the redemption long ago promised shall surely come. ${ }^{x}$ Israel, in spite of her sins, shall be delivered, ${ }^{2}$ Jehovah cannot forget Zion ; consequently she shall be restored. ${ }^{3}$ The whole present situation shall be changed and the future will bring a period of peace. ${ }^{4}$ The time is coming when men everywhere will accept Jehovah ; 5 when the new Jerusalem will be adorned and decorated ${ }^{6}$ when there will be a new heaven and a new earth. ${ }^{7}$ These representations show conclusively that the prophets have detached the ideal future from the local Jerusalem. The new era which Isaiah expected in his day, which Jeremiah predicted would come at the close of the seventy years of captivity, is not ushered in with the restoration of the faithful remnant to Jerusalem. This may be understood as a token of the deliverance still in the future, but it is by no means the deliverance which the prophets had expected, and so Daniel in the last days of the captivity postpones the coming of this glorious time still later by seventy weeks. ${ }^{8}$

7. When, under Zerubbabel, the Jews return to Jerusalem, work is begun at once upon the temple. But after laying the foundation it stops. Some years later, urged by Haggai they

\footnotetext{
Isa. $45: 2$ I-25.

4 Isa. $54:$ I-I $7 . \quad 7$ Isa. $65: 17-25$.

${ }^{2}$ Isa. $48: 17^{-22}$.

5 Isa. $56: 6,7$.

${ }^{8}$ Dan. $9: 24-27$; $12: 1-3$, IO-I3.

3 Isa. $49: 14^{-23}$.

${ }^{6}$ Isa. $62: I-12$.
} 


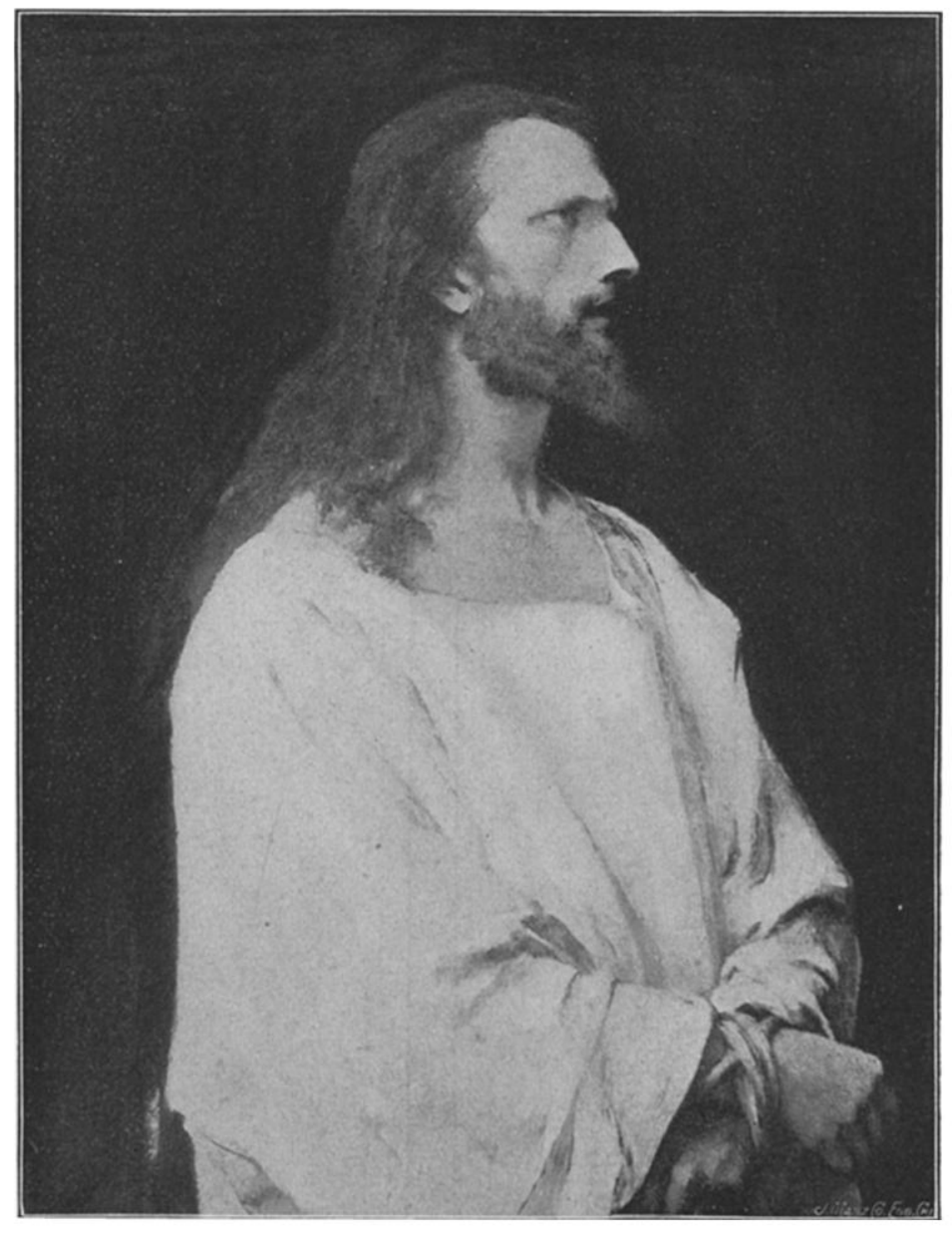

THE REDEEMER,

From Munkacsy's Christ before Pilate.

This content downloaded from 129.100.058.076 on November 27, 2016 07:20:21 AM All use subject to University of Chicago Press Terms and Conditions (http://www.journals.uchicago.edu/t-and-c). 
take up again the building of the temple and in connection with his exhortations Haggai predicts an impending shaking of the nations, which shall mean great things for Israel.' Zechariah, about this time, describes the Jerusalem of the future in contrast with that of the present, ${ }^{2}$ and enlarges upon Jeremiah's prophecies of Israel's king, the Branch. ${ }^{3}$ It is in these later days that Joel, ${ }^{4}$ filled with apocalyptic vision sees a time in the future when Jehovah will pour out his spirit upon all flesh and all men will become prophets.

In connection with this he predicts the destruction of all the nations who oppose Jehovah, ${ }^{5}$ and even of Israel herself, in so far as she does not conform to the divine law. The Psalms of the later period deal most fondly with the coming of Jehovah in judgment, ${ }^{6}$ the manifestation of his presence and his power $;^{7}$ a coming which will bring prosperity to those who love him, and a judgment day for the nations who are opposed to him. ${ }^{8}$ But Malachi, closing the long list of prophets, announces the coming of a second Elijah who shall foretell the coming of a messenger of the covenant whose coming shall be a day of destruction to the wicked and a day of blessing to the righteous. 9

When now we consider the history of Israel as a whole, a history especially conducted by Jehovah, (I) in order to build up a people in the knowledge of himself that through them higher and higher truth might be revealed to the world; (2) in which great and significant events take place, furnishing the object lessons for the inculcation of these important teachings, we cannot fail to recall how, again and again, the inspired speakers refer to the conflict of mankind with evil, announcing that in the end mankind shall conquer. In whom did all these representations find their fulfilment? Who, once for all, gained the victory over sin? We recall the utterance after utterance concerning the day that Jehovah shall appear among men. This coming is always in the future and will be attended with blessings to those who love him, with destruction to those who have

\footnotetext{
I Hag. 2: I-9, 2I-23.

4 Joel $2: 28,29$.

7 Ps. 95.

2 Zech. 2: I-I3.

5 Joel $2: 30-3: 21$.

8 Pss. 98, 99, 100, 85.

3 Zech. 3:6-Io.

${ }^{6}$ Ps. 97.

9 Mal. 3.
} 
opposed him. When has he appeared except in the presence of his son, Jesus Christ? We notice also the vivid portrayals of the day of Jehovah, a day of darkness and distress when hostile nations shall be punished and the people of God redeemed. Does this find its fulfilment in anything else than the new régime which Christ inaugurated? We recall the beautiful descriptions of the Holy Land, as it shall be in the future, where there shall be no death, no sorrow; when man shall be at peace with man and man with beast; when harvests shall be plentiful and everything prosperous; when Jerusalem shall be the great city of the world. We recall how these descriptions enter into the pictures presented to us of the kingdom of God, and we may ask ourselves whether the world has yet seen the fulfilment of these predictions, or whether they are still to come as the outgrowth of the New Testament dispensation, a spiritual land and a spiritual kingdom. We have noted, likewise, how in the divine plan the nation was guided and instructed by three orders of men, each of which in its representations from century to century foreshadows a Christ who shall be at the same time priest, and prophet, and king.

When we remember that there is no such thing as Messianic prophecy in any literature of ancient times except the literature of the Old Testament, and when we consider the definiteness and gradual growth of the full presentation of Messianic prophecy which furnishes the connecting link, from generation to generation, for the whole history and literature of Israel, we may not doubt that in all this there has been exerted an influence for the execution of a divine plan. 